\title{
Overview of measurements capabilities in radiation thermometry at CEM (Spain)
}

\author{
M. J. Martin*, J. M. Mantilla, D. del Campo \\ Centro Español de Metrología, CEM, C/ del Alfar, 2. Tres Cantos, Madrid (Spain)
}

\begin{abstract}
CEM (Spanish National Institute of Metrology) is responsible for the maintenance and dissemination of the temperature national standards. Nowadays, the CEM Radiation Thermometry Laboratory disseminates and maintains the International Temperature Scale of 1990 (ITS-90) from the Ag fixed point $\left(961.78{ }^{\circ} \mathrm{C}\right.$ ) to $2800{ }^{\circ} \mathrm{C}$, using $\mathrm{Ag}$ or $\mathrm{Cu}$ fixed points as reference and standard radiation thermometers (RTs) working at a wavelength of $650 \mathrm{~nm}$. CEM is also able to provide traceability to the new definition of the kelvin and to perform measurements of thermodynamic temperature from $400{ }^{\circ} \mathrm{C}$ to 2800 ${ }^{\circ} \mathrm{C}$ with different RTs (wavelengths of $650 \mathrm{~nm}, 900 \mathrm{~nm}$ and $1550 \mathrm{~nm}$ ) using absolute and relative primary radiation thermometry. In addition the Radiation Thermometry laboratory performs calibration of RTs working in the usual infrared ranges $(1 \mu \mathrm{m}$ and $10 \mu \mathrm{m})$ from $-40{ }^{\circ} \mathrm{C}$ to $1600{ }^{\circ} \mathrm{C}$.
\end{abstract}

\section{Introduction}

The CEM Temperature Division is responsible for the development, maintenance and dissemination of the thermodynamic temperature unit: the.

The Radiation Thermometry Laboratory is long experienced in the dissemination and maintenance of the ITS-90 from the silver fixed point $\left(961.78{ }^{\circ} \mathrm{C}\right)$ to $2800{ }^{\circ} \mathrm{C}$. Recently, CEM has participated in the assignment of -the thermodynamic temperature to the $\mathrm{Cu}, \mathrm{Co}-\mathrm{C}, \mathrm{Pt}-\mathrm{C}$ and $\mathrm{Re}-\mathrm{C}$ fixed points in the frame of the InK EMRP project and has performed measurements of the difference between the thermodynamic temperature $t$ and the temperature defined by the ITS- $90, t_{90}$ (from 420 ${ }^{\circ} \mathrm{C}$ to $1100{ }^{\circ} \mathrm{C}$ ) in the frame of the InK2 EMPIR Project [1], [2].

In addition, CEM has secondary radiation thermometry facilities to perform calibrations of infrared radiation thermometers from $-40{ }^{\circ} \mathrm{C}$ to $1600{ }^{\circ} \mathrm{C}$.

\section{Description}

$2.1 t_{90}$ measurements and dissemination from $\mathrm{Ag}$ to $2800{ }^{\circ} \mathrm{C}$

A picture of the equipment used to measure high temperatures traceable to the ITS-90 is shown in figure 1. The standard RTs used are a KE LP4 and a KE LP2. The thermometers can be referred to a $\mathrm{Cu}$ fixed point (FP) or a Ag FP. The $t_{90}$ is obtained by extrapolation using the relative spectral response of the thermometer, that is measured using a calibrated monochromator model SPEX 750.
The RTs are characterized in linearity and in size of source effect (SSE) using the double flux method and the indirect method, respectively. Variable temperature blackbodies (VTBBs) or high stability lamps are used as sources to measure linearity. An integrating sphere and different spots and apertures are used to measure SSE.

The variable temperature blackbodies available at the laboratory are:

- In the range from $960{ }^{\circ} \mathrm{C}$ to $2200{ }^{\circ} \mathrm{C}$ : CHINO IR$\mathrm{R} 80$ furnace (10 $\mathrm{mm}$ diameter aperture).

- In the range of $2000{ }^{\circ} \mathrm{C}$ to $2800{ }^{\circ} \mathrm{C}$ a $\mathrm{BB} 3200$ furnace (12 $\mathrm{mm}$ diameter aperture).

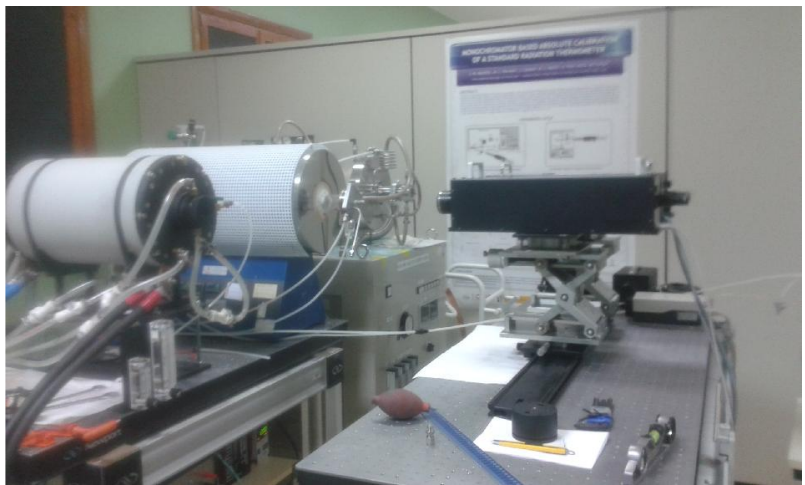

Fig. 1. ITS-90 measurements setup.

$2.2 t$ measurements and dissemination from $400{ }^{\circ} \mathrm{C}$ to $2800{ }^{\circ} \mathrm{C}$

In the last years, CEM, in collaboration with Instituto de Optica of Consejo Superior de Investigaciones Científicas (IO-CSIC), has developed a setup for absolute calibration of standard radiation thermometers

\footnotetext{
Corresponding author: mjmartinh@cem. es
} 
using the radiance method at $650 \mathrm{~nm} \mathrm{[3].} \mathrm{The} \mathrm{aim} \mathrm{is}$ twofold: to realise and disseminate the new definition of the kelvin and to perform the assignement of the thermodynamic temperature to fixed points [4].

In order to carry out these measurements a system based in a monochromator or/and a laser and an integratingsphere is used to calibrate the CEM standard RTs (KELP2 and LP4) [3]. The setup is shown in figure 2.

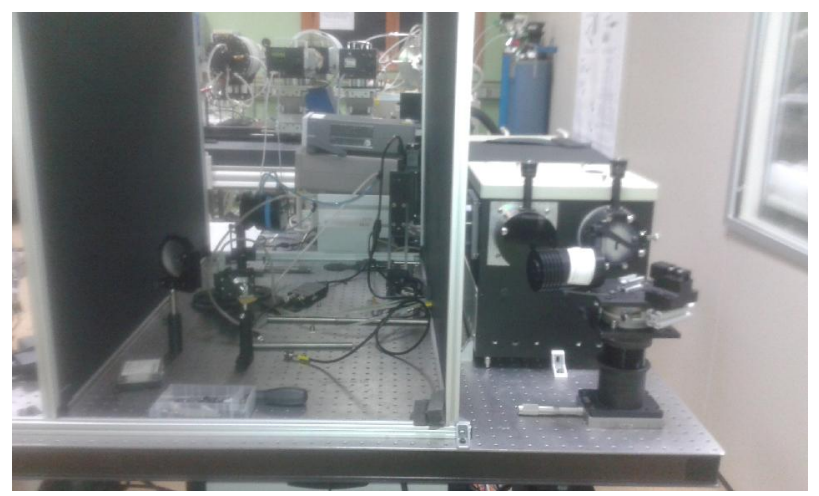

Fig. 2. RTs absolute calibration setup.

In addition to the absolute primary radiation thermometry, relative primary radiation thermometry are also available allowing $t$ measurements below the Ag FP temperature. Both a KE LP4 at $900 \mathrm{~nm}$ and a KE LP5 at $1550 \mathrm{~nm}$ can be used to calculate $t$ by extrapolation from the $t$ Ag FP value (assigned with a KE LP2 or KE LP4 thermometer at $650 \mathrm{~nm}$ ). The range covered by the relative primary radiation thermometry is $400{ }^{\circ} \mathrm{C}$ to the Ag FP temperature [5].

\section{3 t90 measurements and dissemination from $-40{ }^{\circ} \mathrm{C}$ to $1600{ }^{\circ} \mathrm{C}$}

A picture of the equipment used to measure radiation temperature from $-40{ }^{\circ} \mathrm{C}$ to $1600{ }^{\circ} \mathrm{C}$ at $\mathrm{CEM}$ is shown in figure 3. Different VTBBs are used: an ethanol bath ($40{ }^{\circ} \mathrm{C}$ to $\left.30{ }^{\circ} \mathrm{C}\right)$, an oil bath $\left(50{ }^{\circ} \mathrm{C}\right.$ to $\left.180{ }^{\circ} \mathrm{C}\right)$, a Cs heat pipe $\left(200{ }^{\circ} \mathrm{C}\right.$ to $\left.500{ }^{\circ} \mathrm{C}\right)$, a $\mathrm{Na}$ heat pipe $\left(600{ }^{\circ} \mathrm{C}\right.$ to 950 $\left.{ }^{\circ} \mathrm{C}\right)$ and a three zone furnace $\left(950{ }^{\circ} \mathrm{C}\right.$ to $\left.1600^{\circ} \mathrm{C}\right)$.

The maximum diameter of the VTBB's apertures are 70 $\mathrm{mm}\left(-40{ }^{\circ} \mathrm{C}\right.$ to $\left.180{ }^{\circ} \mathrm{C}\right), 30 \mathrm{~mm}\left(200^{\circ} \mathrm{C}\right.$ to $\left.950{ }^{\circ} \mathrm{C}\right)$ and $10 \mathrm{~mm}\left(950{ }^{\circ} \mathrm{C}\right.$ to $\left.1600{ }^{\circ} \mathrm{C}\right)$.

The standards used to measure the VTBB's temperature are:

- Up to $180{ }^{\circ} \mathrm{C}$, Pt100, calibrated by comparison, immersed in the bath liquid touching the cavity.

- From $200{ }^{\circ} \mathrm{C}$ to $950{ }^{\circ} \mathrm{C}$, home-made $\mathrm{Au} / \mathrm{Pt}$ thermocouples calibrated in fixed points and inserted in a boring in the heat pipe parallel to the cavity.

- From $950{ }^{\circ} \mathrm{C}$ to $1600{ }^{\circ} \mathrm{C}$, a VEGA TRTII (900 $\mathrm{nm})$ calibrated as in 2.1 .

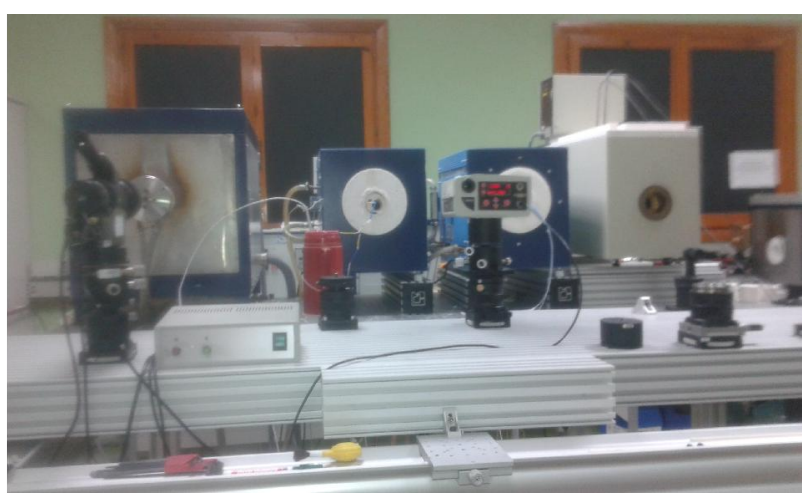

Fig. 3. Secondary radiation thermometry facilities.

\section{Results}

The uncertainties of radiation thermometry measurements capabilities at CEM are:

- $t_{90}$ (from $\mathrm{Ag}$ to $2800{ }^{\circ} \mathrm{C}, 650 \mathrm{~nm}$ ): from $0.2{ }^{\circ} \mathrm{C}$ to $1.8^{\circ} \mathrm{C}[6]$

- $t$ (from $\mathrm{Ag}$ to $2800{ }^{\circ} \mathrm{C}, 650 \mathrm{~nm}$ ): $0.2^{\circ} \mathrm{C}$ to $1.5^{\circ} \mathrm{C}$ [7]

- $t$ (from $400{ }^{\circ} \mathrm{C}$ to $\mathrm{Ag}, 900 \mathrm{~nm}$ and $1550 \mathrm{~nm}$ ): from 0.1

${ }^{\circ} \mathrm{C}$ to $0.2{ }^{\circ} \mathrm{C}[5]$

- $t_{90}$ radiation temperature $\left(-40{ }^{\circ} \mathrm{C}\right.$ to $1600{ }^{\circ} \mathrm{C}, 1 \mu \mathrm{m}$ and $10 \mu \mathrm{m}): 0.5^{\circ} \mathrm{C}$ to $1^{\circ} \mathrm{C}[8]$

\section{Conclusions}

CEM Radiation Thermometry Laboratory can measure and disseminate both $t_{90}$ and $t$ at different ranges using RTs at different wavelengths. The best uncertainties range from $0.2{ }^{\circ} \mathrm{C}$ to $1.5^{\circ} \mathrm{C}$ from $\mathrm{Ag}$ temperature to $2800{ }^{\circ} \mathrm{C}$.

CEM radiation thermometry secondary facilities can supply traceability to infrared RTs from $-40{ }^{\circ} \mathrm{C}$ to $1600^{\circ} \mathrm{C}$, with uncertainties ranging from $0.5^{\circ} \mathrm{C}$ to $1{ }^{\circ} \mathrm{C}$.

\section{References}

1. InK EMRP Project "Implementing the new kelvin". https://www.euramet.org/researchinnovation/search-researchprojects/details/?eurametCtcp_project_show\%5Bpro ject $\% 5 \mathrm{D}=1138$

2. InK2 EMPIR Project "Implementing the new kelvin 2" https://www.euramet.org/researchinnovation/search-researchprojects/details/?eurametCtcp project_show\%5Bpro ject $\% 5 \mathrm{D}=1434$

3. M. J. Martin, J. M. Mantilla, D. del Campo, M. L. Herranz, A. Pons y J. Campos "Performance of different ligth sources for the absolute calibration of radiation thermometers" Int $\mathrm{J}$ Thermophys 38, 138, 2017 DOI 10.1007/s10765-017-2271-1 
4. E. Woolliams et al. "Thermodynamic temperature assignment to the point of inflection of the meeting curve of high temperature fixed points" Phil. Trans. R. Soc. A. 374: 20150044, 2015

5. M. J. Martin "Measurements of $t$ - $t_{90}$ from $420^{\circ} \mathrm{C}$ to $962{ }^{\circ} \mathrm{C}$ " Report on CEM measurements (InK2 WP1)

6. M. J. Martin. CCT-K10 "ITS-90 realisations above the silver point using two transfer radiation thermometers and a set of high temperature fixedpoint blackbody cells" Report on CEM measurements. Nov 2018.

7. J. M. Mantilla, D. J. Woods, R. Emms, M. J. Martin, A.D.W. Todd and D. del Campo "Construction and comparison of high temperature fixed points at NRC and CEM", Tempmeko'19, send.

8. H. McEvoy "EURAMET 658 extension: project to examine underlying parameters in radiance temperature scale realisation". NPL, June 2013 